\title{
FEATURE- VIGNETTE
}

\& REENTRY

\section{Felons Transported to America and Australia}

\author{
by THOM GEHRING \\ California State University, San Bernardino, USA
}

On January 26, 1788 “a fleet of eleven vessels carrying 1,030 people, including 548 male and 188 female convicts," entered Sydney Harbor, Australia (Hughes, R. [1987]. The Fatal Shore. New York: Alfred A. Knopf, p. 2). Most of these convicts were from London, and 431 of them were exiled or transported for minor theft (Hughes, 1987, p. 72), and were 35 years old or less. Typical among the crimes was that of Thomas Gearing, "who created a brief sensation in Oxford in 1786 by breaking into the chapel of Magdalen College and stealing some ecclesiastical plate. For this sacrilege, he was condemned to death, reprieved and then transported for life." (Hughes, 1987, p. 73).

Convict assignment in Australia differed, in law, from its earlier form in America. Many rspectable Americans railed at the influx of felons, which they thought polluted their society. 'In what can Britain show a more Sovereign contempt for us,' wrote an irate Virginian in 1751, 'than by emptying their Jails into our settlements; unless they would likewise empty their Jakes [toilets] on our tables!' But. . .most farmers and merchants in Maryland or Virginia, when offered a chance of convict labor, grabbed it — and paid handsomely for it. The American colonist owned his indentured servants. He had paid for their transportation across the Atlantic, and he expected to be safeguarded against financial loss if they were set free by some 'unforeseen exercise of the Royal Mercy.' Convicts were capital, like slaves, and had been freely traded as such since the early. . . [17 $\left.7^{\text {th }}\right]$ century. 'Our principall wealth consisteth in servants,' wrote the Virginia settler John Pory in 1619. Under the transportation acts of the seventeenth and early eighteenth centuries, therefore, the Crown was bound to pay a convict's owner should it remit his sentence. . . Virginia and Maryland were not penal colonies, but free ones that used felon slaves. In Australia, which had been settled as a jail, no free settler ever paid for a convict's passage from England; and that, in the official view, disposed of the [free] settler's claim to a right of property in the convict's labor. All such rights belonged to the government. Nevertheless, disputes over the 'right' of settlers to sell or reassign their convicts kept raising colonial hackles for decades. (Hughes, 1987, p. 287; emphasis in original).

Transportation of felons to America ended with the American Revolution, and it took the English years before they realized they could transport prisoners to Australia. However, many convict sentiments were unchanged in remote Australia. By 1813, when drinking contraband liquor, Australian convicts had their own traditional toasts. London's 'Newgate [Prison] was called the 'whit' or 'wit,' and all flash lads drank to its destruction. 'The Wit be burnt,' ran a common criminal toast, 'the Flogging Cull (flogger) be damned, the Nubbing Chit (gallows) be curs'd.'” (Hughes, 1987, p. 36). Transportation of felons to the Australian penal colonies continued until 1867, when the colonists in Western Australia refused to accept any more British prisoners (Barry, J. [1958]. Alexander Maconochie of Norfolk Island: A Study of a Pioneer in Penal Reform. Melbourne: Oxford University Press, p. 36).

Thom Gehring is the research director of the Center for the Study of Correctional Education at California 
State University, San Bernardino. His scholarly emphasis is on the history of correctional education and prison reform. He has been a correctional educator since 1972. Thom did his Ph.D. dissertation on the correctional school district pattern of organization. He serves as the historian for the Correctional Education Association. Thom is a professor of education who directs the EDCA correctional and alternative masters degree program. 